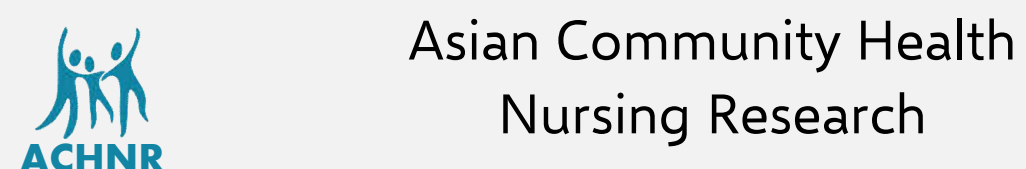

Asian Comm. Health Nurs. Res. 2019, 1(1), 28-33

\title{
The Intervention of Brain Gym in Increasing the Quality of Life on The Elderly
}

\author{
Parellangi Andi 1, Kelana Kusuma Dharma ${ }^{2}$, Edi Purwanto ${ }^{1,}$ Rivan Firdaus 1, and \\ Rina Loriana 1 \\ 1Politeknik Kesehatan Kemenentrian kesehatan Kalimantan Timur, Jl. W. Monginsidi No.38, Sidodadi, \\ Samarinda Ulu, Kota Samarinda, Kalimantan Timur 75243, Indonesia; \\ 2 Politeknik Kesehatan Kemenentrian kesehatan Pontianak, Jl. DR. Soedarso, Bangka Belitung Laut, Pontianak \\ Tenggara, Kota Pontianak, Kalimantan Barat 78124, Indonesia; \\ *Correspondence: andiparel@ymail.com
}

Received: September 15, 2018; Accepted: January 30, 2018; Published: February 3, 2019 https://doi.org/10.29253/achnr.2019.12812

\begin{abstract}
This research aims to find the effect of Brain Gym interventions in improving the quality of life in the elderly after controlling with the confounding variables are age, sex, and education. This research is experimental research with pre and post-test group design and randomizes design. The sample determination based on the inclusion criteria. The sample is 66 people, divided into two groups of 33 respondents respectively. The determination of the group by using the randomize table, then conducted a pre-test in both groups by using the WHOQOL-BREF's questionnaire. Group 1 was given 10 minutes gym/exercise with the frequency of three times a week and physical activity, while group 2 was a control. The brain gym and physical activity interventions were given for a month and then conducted a post-test. The research data were analyzed by using a paired sample t-test independent sample t-test, ANCOVA, Chi-Square, and Kolmogorov-Smirnov. The result showed that $\mathrm{p}$ $=0,000<0,05$ and the mean quality of life improvement in group gym for 10 minutes/exercise with the frequency of three times in a week were $9.48 \pm 3.104$ while in group 2 as the control was $2.15 \pm$ 1.372. The brain gym for 10 minutes/exercise with the frequency of three times a week affects improving the quality of life in the elderly.
\end{abstract}

Keywords: Brain gym, physical activity, quality of life

\section{Introduction}

The number of elderly people in 2000 is $7.18 \%$ of the total population in Indonesia and increased to $9.77 \%$ in 2010 and projected in 2020 will increase to $11.34 \%$. The increasing number of elderly from year to year will be a challenge, especially for health workers because if it is not managed properly, then it will cause a burden for the state (Health Ministry of Republic of Indonesia, 2014).

In the elderly, people will undergo a change in physical, cognitive, and psychosocial life (Papalia, et al, 2009). Darnton-Hill (Gureje, 2008) also stress the importance of life expectancy and quality of life for the elderly. The four domains in the quality of life are physical health, psychological health, social relations, and environmental aspects (Brown, 2004).

The previous studies stated that the intervention of brain gym timing of 10 minutes/exercise and the frequency of three times in a week is more effective in improving the cognitive function of the elderly, while it is compared with a 15 minutes gym/exercise gym and the frequency of two times a 
week (Parellangi, 2018). The previous research was also the Exercise Prescription for Physical Fitness recommends the exercise frequency at least three times a week to improve V02max. The increasing of V02max may improve the elderly cognitive function (Pollock, Feigenbaum, \& Brechue, 1995). Based on the above things, it is deemed necessary to conduct research on "Brain Gym Intervention Improving Quality of Life in Elderly at Social Institution of Tresna Wredha Nirwana Puri Samarinda". Furthermore, this study aims to find the effect of Brain Gym in improving quality of life in elderly after controlled by the confounding variable, such as age, gender, and education.

\section{Methods}

Study design and participants: This research is experimental research by using the randomised design, pre-test and post-test group design. This research was conducted at Social Institution of Tresna Werda Nirwana Puri Samarinda and Panti Werdha Sinar Abadi Singkawang West Kalimantan in August to November 2017.

The sample size is determined by taking all members of the population into samples according to the inclusion criteria is 66 people, then conducted a simple random sampling by using a random number generator is a Research Randomizer program to determine the group. There consists of two groups, each of group is 33 people. Group 1 is 10 minutes/exercise, the frequency is three times a week) and Group 2 is as a control group.

The instrument used is the questionnaire instruments of the WHOQOL - BREF from World Health Organization (WHO), which consisting of 26 questions. These questions include four dimensions of physical health, psychological well-being, social relations and environmental relations. The data analysis in this study is using a Paired t-test, Independent t-test, ANCOVA, Chiquere and KolmogorovSmirnov.

\section{Results}

Table 1 shows the characteristics of respondents in group 1 based on the age of the average age of respondents is $71.21 \pm 8.975$, and most of them are male sex, which is $54.5 \%$, and the Elementary level is $33.3 \%$. While, the characteristics of respondents in group 2 based on the age of the average age of respondents are $67.79 \pm 4.037$, and some of them are female sex is $63.6 \%$, and all of them did not complete their elementary school is $100 \%$.

Table 1. Respondent Characteristic.

\begin{tabular}{|c|c|c|c|c|c|c|c|c|}
\hline \multirow[t]{2}{*}{ No } & \multirow[t]{2}{*}{ Characteristic } & \multicolumn{3}{|c|}{ Group 1} & \multicolumn{3}{|c|}{ Group 2} & \multirow[t]{2}{*}{$\mathbf{N}$} \\
\hline & & Mean \pm ES & $\mathbf{n}$ & $\%$ & Mean \pm ES & $\mathbf{N}$ & $\%$ & \\
\hline 1. & Age & $67.79 \pm 4.037$ & & & $71.21 \pm 8.975$ & & & 66 \\
\hline \multirow[t]{3}{*}{2.} & Gender & & & & & & & 66 \\
\hline & Male & & 15 & 45.5 & & 12 & 36.4 & \\
\hline & Female & & 18 & 54.5 & & 21 & 63.6 & \\
\hline \multirow[t]{7}{*}{3.} & Last Education & & & & & & & 66 \\
\hline & Not Pass Elementary & & 8 & 24.2 & & 33 & 100 & \\
\hline & School & & & & & & & \\
\hline & Elementary School & & 11 & 33.3 & & & & \\
\hline & Junior High School & & 5 & 15.2 & & & & \\
\hline & Senior High School & & 8 & 24.2 & & & & \\
\hline & Higher Education & & 1 & 3.0 & & & & \\
\hline
\end{tabular}


Table 2 shows the results of normality test (Saphiro Wilk Test), quality of life of respondents in group 1 before given the brain gym and physical activity is $p=0.055$, and after given the brain gym and physical activity is $p=0.075$, and the difference before and after given the brain gym is $p=0.152$.

Table 2. Test Normality and Homogeneity Test.

\begin{tabular}{llll}
\hline Quality of Life & Levene Test & $\begin{array}{l}\text { Saphiro Wilk Test } \\
\text { Group 1 }\end{array}$ & $\begin{array}{l}\text { Group 2 } \\
\text { P }\end{array}$ \\
\cline { 2 - 4 } Pre Test & $\mathbf{P}$ & 0.055 & 0.205 \\
Post Test & 0.179 & 0.075 & 0.366 \\
Deviation & 0.096 & 0.152 & 0.058 \\
\hline
\end{tabular}

Source: Primary Data Analysis, 2017

The result of paired sample t-test shows the average value of mean \pm Elementary School's quality of life of respondent in group 1 before given brain gym and physical activity is $52,91 \pm 3,884$, and after given a brain gym is to $61,91 \pm 3,761$, and the difference before and after given a brain gym and physical activity is $9,33 \pm 3,149$ (Table 3 ).

Table 3. Test of Mean Differences Improved Quality of Life.

\begin{tabular}{lcccc}
\hline & Before & $\begin{array}{c}\text { Quality of Life } \\
\text { After }\end{array}$ & Deviation & p \\
\hline Group 1 & $52.91 \pm 3.884$ & $61.91 \pm 3.761$ & $9.33 \pm 3.149$ & 0.000 \\
(Intervention) & $69.70 \pm 2.663$ & $71.85 \pm 2.017$ & $2.15 \pm 1.372$ & 0.000 \\
Group 2 & & & \\
(Control) & & & \\
\hline
\end{tabular}

Source: Primary Data Analysis, 2017

Table 3 shows the average value of mean \pm Elementary School's quality of life of respondent in group 2 before it is controlled is $69.70 \pm 2.663$, and after controlling is $71.85 \pm 2.017$, and the difference before and after controlled is $2.15 \pm 1.372$.

Table 3 shows the p-value in group 1 before and after the brain gym and physical activity intervention is 0.000 , and in group 2 before and after controlled is 0.000 , ( $p$-value $=0.05$ ). Based on the data above shows that there is an improvement of the quality of life in group 1 before and after the brain gym intervention and in group 2 before and after controlled.

The test result of the independent sample t-test shows the differences in the quality of life improvement in group 1, which is given the intervention of brain gym and physical activity with group 2 as the control. Based on the table obtained the Levene test results $\mathrm{p}=0.002<0.05$. So, it can be concluded that the data comes from different variants (Table 4).

Table 4. Test the Average Difference of Quality of Life Improvement.

\begin{tabular}{lllll}
\hline & Group & Mean \pm ES & Levene Test & p-value \\
\hline Deviation & $\begin{array}{l}\text { Group 1 } \\
\text { (intervention) }\end{array}$ & $9.33 \pm 3.149$ & 0.002 & 0.000 \\
& $\begin{array}{l}\text { Group 2 } \\
\text { (Control) }\end{array}$ & $2.15 \pm 1.372$ & & \\
\hline
\end{tabular}
Source: Primary Data Analysis, 2017

Table 4 shows the $\mathrm{p}$ value $=0.000<0.05$ and the average quality of life improvement in group 1 with the brain gym interventions are $9.33 \pm 3.149$, while in group 2 (control) is $2.15 \pm 1.372$. When its views on the average that increase in both groups it can be concluded that brain gym more influential in improving the quality of life of respondents.

The results of the ANCOVA test shows the differences in quality of life improvement in group 1 given the intervention of brain gym and physical activity with group 2 (control). Based on the table obtained the results of p-value $=0.00<0.05$. So, it can be concluded that the brain gym influential in improving the quality of life of respondents by controlling the age of respondents (Table 5). 
The results of Chi-Square Test shows the difference in quality of life improvement in group 1 given the intervention of brain gym with group 2 (control). Based on the table obtained the results of $p$ value $=0.453<0.05$. So, it can be concluded that the brain gym and physical activity influential in improving the quality of life of respondents by controlling the sex of respondents (Table 6).

Table 5. ANCOVA Quality Life's Test.

\begin{tabular}{lccccc}
\hline \multicolumn{1}{c}{ Source } & Type I Sum of Squares & Df & Mean Square & F & p-value \\
\hline Corrected Model & 848.437 a & 2 & 424.218 & 70.297 & .000 \\
Intercept & 2176.379 & 1 & 2176.379 & 360.646 & .000 \\
Groups * ages & 848.437 & 2 & 424.218 & 70.297 & .000 \\
Error & 380.184 & 63 & 6.035 & & \\
Total & 3405.000 & 66 & & & \\
Corrected Total & 1228.621 & 65 & & & \\
a. R Squared =.691 (Adjusted R Squared =.681) & & & & \\
\hline
\end{tabular}

Source: Primary Data Analysis, 2017

Table 6. Chi-Square Test for Quality of Life.

\begin{tabular}{lccccccc}
\hline \multirow{2}{*}{ Genders } & \multicolumn{2}{c}{ Intervention } & \multicolumn{2}{c}{ Control } & \multicolumn{2}{c}{ Total } & \multicolumn{1}{c}{ P } \\
& $\mathbf{N}$ & $\mathbf{\%}$ & $\mathbf{N}$ & $\mathbf{\%}$ & $\mathbf{N}$ & $\mathbf{\%}$ & \\
\hline Male & 15 & 45.5 & 12 & 36.4 & 27 & 40.9 & 0.453 \\
Female & 18 & 54.5 & 21 & 63.6 & 39 & 59.1 & 100 \\
Total & 33 & 100 & 33 & 100 & 66 &
\end{tabular}

The Kolmogorov-Smirnov Test results show the difference in the quality of life improvement in group 1 given the brain gym intervention with group 2 (control). Based on the table obtained the results of $p$-value $=0.00<0.05$. So, it can be concluded that the brain gym and physical activity influential in improving the quality of life of respondents by controlling the education of respondents (Table 7).

Table 7. Kolmograf-Smirnov Test for Quality of Life.

\begin{tabular}{llr}
\hline & & Education \\
\hline Most Extreme Differences & Absolute & .758 \\
& Positive & .000 \\
& Negative & -.758 \\
Kolmogorov-Smirnov Z & & 3.077 \\
P-value (2-tailed) & & 0.000 \\
\hline
\end{tabular}

Source: Primary Data Analysis, 2017

\section{Discussion}

According to WHO states the quality of life is an individual's perception of their position in life in the context of the cultural system and the value in which they live, and in relation to their goals, expectations, standards, and problems (Billington et al., 2016).

In measuring the quality of life for each individual by using a questionnaire of the WHOQOL-BREF, which consists of 26 items, with 24 items grouped into four domains or subscale that physical health domain (seven items), psychological domain (six items), social relations domain (three items), environment domain (eight items), and includes one item of overall quality of life and one general health item (Gobbens \& Assen, 2016). 
Through of the WHO standard of quality of life, it contains in the questionnaires of the WHOQOLBREF that have been used to assess the quality of life in sick individuals, chronic fatigue syndrome, depression, psychosis, earthquakes, adults, and the elderly (Skevington \& Mccrate, 2011).

In improving the quality of life in the elderly after doing a brain gym and physical activity intervention is attributed to brain intervention and physical activity training elderly to concentrate, stimulate intellectual elderly, improve fitness and reduce cardiovascular risk factors. So, it can increase blood flow and blood supply volume to the brain, which causes oxygen supply to brain increases and affects the nerve degeneration (Parellangi, 2018). When doing a brain gym and physical activity, the elderly do a social interaction quite often with the same elderly as well, or even health officer, this is good on improving their quality of life, because based on the previous research, social interaction effect in improving the quality of life of elderly with the p-value 0,004 (Katuuk, 2017).

The other factors that affect the quality of life of the elderly are age, education level, gender, and lack of physical activity. When it's viewed from the characteristics of respondents, which almost half of them just graduated from Elementary School is 33.3\% in group 1, all of them did not pass even Elementary School is $100 \%$. This is supported by the previous research which states that their education affects the elderly themselves, both in terms of cognitive function or quality of life of the elderly. The physical activity is performed by the elderly in the form of sewing and a cook can prevent the cognitive decline, this will certainly be aligned in improving the quality of life of the elderly (Parellangi, 2018).

The respondents who were given intervention in 10 minutes gym/exercise, physical activity, and the frequency of three times a week by controlling the variables of age, sex, and education could have an effect in improving the quality of life of the responders. This is in accordance with the research results obtained after the test age with ANCOVA obtained p-value $=0,000<0.05$, and after sex and testing with Chi-Square Test obtained p-value $=0.453>0.05$, and education after testing with Kolmogorov-Smirnov Test obtained p-value $=0.000<0.05$. It means that there is an influence of brain gym intervention in 10 minutes/exercise and the frequency of three times a week and physical activity with controlling the age, gender, and education of the respondent.

The brain gym and physical activity is a method that requires a movement of organs, physical activity is also able to improve the quality of life in heart patients (Bocalini, Santos, Andrey, \& Serra, 2008). In addition, physical activity can also be used to help improve the quality of life of breast cancer patients (Hilton, Trigg, \& Minniti, 2015). This is supported by the previous research, which is showing that 10-minutes of brain training and the frequency of three times in a week are more effective in improving the cognitive function of the elderly than with a 15-minutes brain gym/exercise and the frequency of two times in a week (Parellangi, 2018).

\section{Conclusions}

There is improvement of the quality of life in elderly after giving a Brain Gym intervention is 9. 48 \pm 3.104 , with the $\mathrm{p}$ value $=0.000(\mathrm{p}<0.05)$, and the control group is $2.15 \pm 1.372$, with the $\mathrm{p}$ value $=$ $0.000(\mathrm{p}<0.05)$. There are differences in the quality of life of the elderly after giving a brain gym intervention in Group 1 that is $9.48 \pm 3.104$, and after controlling the group 2 is $2.15 \pm 1.372$, and $p$ value $=0.000(p<0.05)$.

Conflicts of Interest: there is no conflict of interest.

Acknowledgement: The author realizes that the preparation of this research can be completed because of the help and support from various parties. Therefore, on this occasion, the author is expressing his gratitude and appreciation to the honourable:

1. Drs. H. Lamri, M.Kes., As Director of State Health Polytechnic of the Health Ministry of East Kalimantan.

2. Dr. Hj. Endah Wahyutri, M.Kes, as the Head of Research Unit of State Health Polytechnic of the Health Ministry of East Kalimantan.

3. Head of Social Institution Tresna Wredha Nirwana Puri Samarinda, which has given the opportunity in doing research.

4. Head of Werdha Singkawang Orphanage, West Kalimantan, which has provided the opportunities in conducting research.

5. All Lecturers at State Health Polytechnic of the Health Ministry of East Kalimantan.

6. All parties who have assisted in the completion of this competing of the research grant. 


\section{References}

Asosiasi Alzheimer Indonesia. (2003). National Consensus Introduction and Management of Alzheimer Dementia and Other Dementia, Edition 1.

Billington, D. R., Hsu, P. H., Kra, C. U., Feng, J., Medvedev, O. N., Kersten, P., ... Siegert, R. J. (2016). Ordinal-ToInterval Scale Conversion Tables and National Items for the New Zealand Version of the WHOQOL-BREF, 1-15. https://doi.org/10.1371/journal.pone.0166065

Bocalini, D. S., Santos, I. L., Andrey, I. I., \& Serra, J. (2008). Physical exercise improves the functional capacity and quality of life in patients with heart failure, 437-442. https://doi.org/10.1590/S180759322008000400005

Brown, Jackie, et all. (2004). Models of Quality of Life : A Taxonomy, Overview and Systematic Review of The Literatur. European Forum on Population Ageing Research, p. 6, 8, 46

Darmojo, Martono. (2000). Mild Cognitive Impairment (MCI), Periodical Neuro science, 1 (1): 11-15

Dennison, Paul E. \& Gail E. Dennison, (2008). The Comprehensive Guidance Book of Brain Gym Jakarta: Grasindo

Effendi, F \& Makhfudli. (2009). Nursing Community Theory \& Practice in Nursing. Jakarta : Salemba Medika

Farizati Karim, (2002). Guidelines for Health Care for Health Workers, Jakarta : Health Ministry of Republic of Indonesia.

Gelder, B. M., Tijhuis, M., Kalmijn, S., Giampaoli, S., Nissinen, A, Kromhout. (2006). Marital Status and Living Situation During 5 Years Period Are Associated With A Subsequent 10 Years Cognitive Decline in Older Men: The FINE Study. The Journal or Gerontology Series, 61:213-219.

Gureje, O; Kola, L; Afolabi, E \& Olley, B.O (2008) Determinants of quality of life of elderly Nigerians: results from the Ibadan Study of Ageing. African Journal of Medicine and Medical Sciences. 37(3): 239-247

Gobbens, R. J. J., \& Assen, M. A. L. M. Van. (2016). Psychometric properties of the Dutch. Health and Quality of Life Outcomes, 1-9. https://doi.org/10.1186/s12955-016-0508-5

Hardywinoto, Setiabudhi, T. (1999). Gerontology Guide Overview of Various Aspects. Jakarta: Gramedia Pustaka Utama

Hilton, C., Trigg, R., \& Minniti, A. (2015). Improving the psychological evaluation of exercise referral : Psychometric properties of the Exercise Referral Quality of Life Scale. https://doi.org/10.1177/2055102915590317

Johnson, M.H. (2005). Developmental Cognitive Neuroscience, ed.2. Oxford: Blacwell Publishing

Kathy Gunter. (2002). Healthy, Active aging: Physical Aktivity Guidelines for Older Adults. Oregon State University

Katuuk, M. E. (2017). North Sulawesi Province, 5.

The Health Ministry of Republic of Indonesia, (2014) Data and Information Center: Situation and Aged Analysis. The Health Ministry RI.

Kirk-Sanchez, N. J., \& McGough, E. L. (2014). Physical exercise and cognitiv performance in the elderly: current perspectives. Clinical Interventions in Aging, 9, 51-62. https://doi.org/10.2147/CIA.S39506

Kurlowiez L., Wallace M. (1999). The Mini Mental State Examination. Journal geriatric nursing, 3(1):10-11.

Lautenschlager, Nicola T., Cox, K., Cyarto, Elizabeth V. (2011). The influence of exercise on brain aging and dementia.The Fine Study. The Journal of Biochimica et Biophysica Acta 1822 (2012) 474-481

Mangoenprasodjo, S., A., dan Hidayati, N., S., (2005). Getting A Happy Old Day. Jakarta: Pradipta Publishing.

Papalia, D.E., Olds, S.W., \& Feldman, R.D. (2009). Human Development. 11th Ed. New York: McGraw-Hill Companies, Inc.

Parellangi, (2018)., Efect Of Light and Medium Intensity Brain Gymnastics on The Improvement of Cognitive Fungtion in Elderly. Belitung Nursing Journal 2018 October ;4(5):518-523

Pocock, S.J. (2008). Clinical Trials, A Practical Approach, Cichestes, John Wiley

Pollock, M. L., Feigenbaum, M. S., \& Brechue, W. F. (1995). Exercise Prescription for Physical Fitness. Quest, 47, 320 - 337. https://doi.org/10.1080/00336297.1995.10484161

Rejeski, W. J., \& Mihalko, S. L. (2017). Physical Activity and Quality of Life in Older Adults, 56(Ii), 23-35.

Saladin, K . (2007). Anatomy and physiology the unity of form and function. 4th ed. New York: McGraw-Hill Companies inc:513-561.

Sidiarto, L. D., Kusumoputro, S. "Mild Cognitive Impairment (MCI) GangguanKognitif Ringan”. Berkala NeuroSains Vol.1.No.1, Oktober 1999.

Skevington, S. M., \& Mccrate, F. M. (2011). Expecting a good quality of life in health : assessing people with diverse diseases and conditions using the WHOQOL-BREF, 49-62. https://doi.org/10.1111/j.13697625.2010.00650.x

Sulianti, A. t.t. Utilization Moment 17 August as a Sports Therapy Training of Therapeutic Recreation for Elderly. Available from:URL:http:/www.koni.or.id/files/documents/journal/2 